\title{
Sucrose and invertases, a part of the plant defense response to the biotic stresses
}

\author{
Alexandra S. Tauzin ${ }^{+\neq}$and Thierry Giardina ** \\ CNRS, Centrale Marseille, iSm2 UMR 7313, Aix Marseille Université, Marseille, France
}

Edited by:

Vincenzo Lionetti, Sapienza

"Università di Roma," Italy

Reviewed by:

Zuhua He, Chinese Academy of

Sciences, China

Ingo Bergmann, Leibniz Institute for

Agricultural Engineering

Potsdam-Bornim e.V. (ATB),

Germany

\section{*Correspondence:}

Thierry Giardina, CNRS, Centrale

Marseille, iSm2 UMR 7313, Aix

Marseille Université, Avenue

Escadrille Normandie-Niemen,

13397 Marseille, France

e-mail: thierry.giardina@univ-amu.fr

${ }^{\dagger}$ Present address:

Michael Smith, Laboratories and

Department of Chemistry,

University of British Columbia,

Vancouver, Canada

¥ These authors have contributed

equally to this work.
Sucrose is the main form of assimilated carbon which is produced during photosynthesis and then transported from source to sink tissues via the phloem. This disaccharide is known to have important roles as signaling molecule and it is involved in many metabolic processes in plants. Essential for plant growth and development, sucrose is engaged in plant defense by activating plant immune responses against pathogens. During infection, pathogens reallocate the plant sugars for their own needs forcing the plants to modify their sugar content and triggering their defense responses. Among enzymes that hydrolyze sucrose and alter carbohydrate partitioning, invertases have been reported to be affected during plant-pathogen interactions. Recent highlights on the role of invertases in the establishment of plant defense responses suggest a more complex regulation of sugar signaling in plant-pathogen interaction.

Keywords: sucrose, cell wall invertase, vacuolar invertase, alkaline/neutral invertase, plant defense response

\section{INTRODUCTION}

Cash and subsistence crops are susceptible to a large number of diseases caused by plant pathogens. Among pathogenic organisms: fungi, oomycetes, viruses and bacteria are the most important ones. The direct consequence of pathogen attack is the decrease of the crop yield. In addition to economic loss, consumer health may be compromised due to risks in ingesting toxins produced from secondary metabolites of these pathogens. Mycotoxins are probably the most known factors produced by fungi, which are not only poisonous but also carcinogenic for human (Maresca, 2013).

The plant response is mediated by a sophisticated immune system divided into two different pathways. The first is microbialassociated molecular-patterns-triggered immunity (MTI), constituted by elicitors recognized by the plant innate immune systems via pattern recognition receptors (PRRs) (Ausubel, 2005; Katagiri and Tsuda, 2010). The second is the effector-triggered immunity (ETI) stimulated on the basis of the perception of pathogen effectors by plant disease resistance proteins (Dangl and Jones, 2001; Jones and Dangl, 2006).

Pathogens modify the host metabolism which results in an energy increase and production of carbon sources (Thines et al., 2000) including sucrose and its cleavage products, glucose and fructose (Roitsch and Gonzalez, 2004; Rolland et al., 2006). Sucrose hydrolysis is catalyzed by invertases, and the consequence is the shifts of the apoplastic sucrose/hexose ratio in favor of hexoses. The aim of this paper is to review recent evidence on the crucial roles of invertases during plant pathogen attacks and how the invertase activity is regulated.

\section{FROM CARBOHYDRATE PARTITIONING TO PLANT DEFENSE RESPONSE \\ SUCROSE SIGNAL MOLECULE}

In higher plants, sucrose is the major transport form of carbohydrates. Sucrose is produced during photosynthesis in source tissues (leaves), and then transported via the phloem to the different sink tissues (roots, stem, reproductive organs and vegetative storage organs) to provide the carbon and energy needed for growth and synthesis of storage reserves.

The role of sucrose as signaling molecule is well established (for reviews see Koch, 2004; Rolland et al., 2006; Wind et al., 2010; Tognetti et al., 2013). It affects plant development processes such as plant growth, regulation of flowering, differentiation of vascular tissue and development of storage organs (for review see Tognetti et al., 2013). Sucrose cleavage products, glucose and fructose, also act as signaling molecules. Of the two hexoses, glucose has been better described in relation with the hexokinase signaling pathway (Moore et al., 2003; Cho et al., 2009) while for fructose a specific pathway has been proposed involving the abscisic acid (ABA)- and ethylene-signaling pathway (Cho and Yoo, 2011; Li et al., 2011). 
Gomez-Ariza et al. (2007) observed that the pre-treatment of rice plants with sucrose drastically reduced symptoms of fungal Magnaporthe oryzae infection and they proposed sucrose as a signal molecule in plant immunity.

\section{PLANT INVERTASES}

Invertases (EC.3.2.1.26) hydrolyze irreversibly sucrose into glucose and fructose. Three groups were identified: alkaline/neutral invertases (A/NInv) localized in the cytosol, mitochondria and/or in plastids, and two types of acid invertases, insoluble bound to the cell wall (cell wall invertase, CWI) and soluble found in the vacuole space (vacuolar invertase, VI), respectively.

\section{ACID INVERTASES AND PROTEINACEOUS INHIBITORS}

Acid invertases, CWIs and VIs, belong to the GH32 family. CWIs play a key role in sucrose partitioning, plant development and cell differentiation while VIs are involved in cell expansion, sugar storage and regulation of cold induced sweetening (Roitsch and Gonzalez, 2004). Both are post-translationally regulated by proteinaceous inhibitors (INHs) which belong, with pectin methylesterase inhibitors (PMEIs), to the pectin methylesterase inhibitor related protein (PMEI-RP) family (Pfam 04043) (Hothorn et al., 2004).

During plant infection, the level of VI modulation is poorly understood with contradictory reports in the literature that leads to an unclear functional assignment (Table 1). On the one hand, a reduction of VI expression has been observed during the infection of Vicia faba by Uromyces fabae and Vitis vinifera by Erysiphe necator and Plasmopora viticola (Voegele et al., 2006; Hayes et al., 2010). This down-regulation was attributed to a decrease in the availability of sucrose in the storage compartment (Voegele et al., 2006; Hayes et al., 2010). By contrast, a high VI activity was observed during the first stage of infection of castor beans by Agrobacterium tumefaciens that might suggest a supportive function during invasion (Wachter et al., 2003). Moreover, the expression of a VI (TIV-1) is not affected in tomato infected by Botrytis cinerea (Hyun et al., 2011). Finally, when Essmann et al. compared wild type tobacco plants and transgenic plants silenced for CWI after infection by Phytophthora nicotianae, they noticed no significant changes in the VI activity (Essmann et al., $2008 \mathrm{a}, \mathrm{b})$ suggesting that the VI is not involved in the plant defense response. These results reinforce the doubts concerning the exact role of VIs in plant immunity.

By contrast, the link between plant response against pathogen and CWI activity has been widely studied (Table 1). A common trend is observed for the rapid increase of the CWI mRNA level after infection by bacterial, fungal, viruses, oomycetes and nematodes (for detailed references see Table 1). Indeed, the up-regulation of CWI activity is essential to modulate sugar partitioning and provide the sugars which are necessary for the pathogen development. A clear example has been demonstrated for gall development in A. thaliana (Siemens et al., 2011). Moreover, it was shown that during infection CWI activity also triggers plant defense responses such as induction of defenserelated gene expression, callose deposition and reduction of photosynthesis or cell death. CWI silencing disrupts the ability of transgenic plants to answer correctly to the pathogen attacks and impairs the defense induced reaction (Essmann et al., 2008a). In rice, the loss-of-function mutant of the CWI gene GRAIN INCOMPLETE FILLING 1 (GIF1) has been demonstrated to be hypersusceptible to postharvest pathogens while the constitutive expression of GIF1 enhances the resistance to pathogens by activating the plant defense response (Sun et al., 2013). In the particular case of symbiosis (such as arbuscular mycorrhiza), the expression of CWI is finely controlled by the partner to prevent the induction of pathogenesis-related (PR) genes and promote "long-term" interaction (Schaarschmidt et al., 2006, 2007).

Invertase activity is potentially modulated by proteinaceous inhibitors (INHs) in a pH-dependent manner (Tauzin et al., 2014). Greiner et al. (1998) demonstrated that tobacco INH didn't affect invertases purified from two fungi, Candida utilis and Saccharomyces cerevisiae, supporting the idea that INHs are not involved in plant defense mechanisms. However, a strong repression of the expression of one of the three INHs from A. thaliana after infection by Pseudomonas syringae pv. tomato DC3000 was documented (Bonfig et al., 2010). The invertase activity was detectable only in infected plants while the enzyme was present in infected and uninfected crude extract cells, indicating that the enzyme activity was repressed by a specific inhibitor. This result was corroborated by the utilization of the pseudo tetrasaccharide acarbose which inhibits invertase activity in planta resulting in an increased susceptibility of the infected plant compared to the wild type (Bonfig et al., 2010).

\section{ALKALINE/NEUTRAL INVERTASES}

A/NInvs are non-glycosylated proteins and they belong to the GH100 family (Lammens et al., 2009). They have different subcellular localizations such as cytosol, mitochondria, chloroplast and nuclei (Vargas and Salerno, 2010). A/NInvs are involved in plant growth and development, flowering and seed germination (Jia et al., 2008; Barratt et al., 2009; Welham et al., 2009). Xiang et al. (2011) demonstrated that A/NInvs are part of the antioxidant system involved in cellular reactive oxygen species homeostasis. Moreover, exogenous application of gibberellic acid (GA) rescued the delay of germination in the seeds of the A/NInv mutants suggesting a communication between $\mathrm{A} / \mathrm{NInv}$ and phytohormones (Xiang et al., 2011; Martin et al., 2013).

Correlated with the increase of the CWI activity, an increase of the A/NInv activity has been observed in Pisum sativum, tobacco and $A$. thaliana during infection by powdery mildew (Storr and Hall, 1992), oomycetes (Essmann et al., 2008a), and the beet curly top virus (Park et al., 2013), respectively. Interestingly, in transgenic tobacco plants silenced for CWI, the A/NInv activity remained unchanged during the interaction with the oomycetic phytopathogen (Essmann et al., 2008a). The authors suggested that the CWI activity increased first and by consequence the availability of carbohydrate changes and triggers the A/NInvs activity as a secondary phenomenon in the plant immunity (Essmann et al., 2008a). By contrast, the infections of $A$. thaliana by two different nematodes Heterodera schachtii and Meloidogyne javanica led to the down-regulation of $A / N I n v$ gene (AtCINV1) reflected by a decrease of activity (Cabello et al., 2013). Thus, the importance of A/NInv might vary depending on the pathosystem. 
Table 1 | Summary of plant pathogen interaction studies referring to invertase modulations.

\begin{tabular}{|c|c|c|c|c|}
\hline Microorganism & Plant & Effects on invertase & Additional features & References \\
\hline \multicolumn{5}{|l|}{ BACTERIA } \\
\hline Erwinia carotovora & Carrot & CWI $(+)$ & Induction of $P A L$ & $\begin{array}{l}\text { Sturm and Chrispeels, } \\
1990\end{array}$ \\
\hline $\begin{array}{l}\text { Agrobacterium } \\
\text { tumefaciens }\end{array}$ & Ricinus communis & CWI $(+) \mathrm{VI}(+)$ & Change in sugar content, ABA synthesis & Wachter et al., 2003 \\
\hline $\begin{array}{l}\text { Xanthomonas } \\
\text { campestris pv } \\
\text { vesicatoria }\end{array}$ & Tomato & CWI $(+)$ & $\begin{array}{l}\text { Change in sugar content, induction of } \\
\text { senescence-associated and } P R \text { genes }\end{array}$ & Kocal et al., 2008 \\
\hline $\begin{array}{l}\text { Xanthomonas } \\
\text { campestris pv } \\
\text { vesicatoria }\end{array}$ & Pepper & CWI $(+)$ & Induction of defense response $P R-Q$ & Sonnewald et al., 2012 \\
\hline Bois noir & Grapevine & CWI $(+)$ & Callose deposition, modulation of SUC genes & Santi et al., 2013a,b \\
\hline $\begin{array}{l}\text { Xanthomonas oryzae } \\
\text { pv. oryzae }\end{array}$ & Rice & CWI $(+)$ & $\begin{array}{l}\text { Change in sugar content, callose deposition, } \\
\text { induction of } P R \text { genes, ROS accumulation }\end{array}$ & Sun et al., 2013 \\
\hline \multicolumn{5}{|l|}{ FUNGI } \\
\hline \multicolumn{5}{|l|}{ Biotrophic } \\
\hline Erysiphe pisi & Pisum sativum & CWI/NI (+) A/NInv (+) & Decrease of starch content & Storr and Hall, 1992 \\
\hline Puccinia hordei & Barley & CWI/NI $(+)$ & ND & Tetlow and Farrar, 1992 \\
\hline Blumeria graminis & Barley & CWI $(+) \mathrm{VI}(+)$ & $\begin{array}{l}\text { Change in sugar content, down-regulation of } \\
\text { photosynthesis, callose deposition, induction of } \\
\text { defense response PR-1 }\end{array}$ & $\begin{array}{l}\text { Scholes et al., 1994; Wright } \\
\text { et al., 1995; Swarbrick } \\
\text { et al., } 2006\end{array}$ \\
\hline Blumeria graminis & Wheat & CWI $(+) \mathrm{VI}(+)$ & ND & Greenshields et al., 2004 \\
\hline Blumeria graminis & Wheat & CWI (+) VI (+) A/NInv (+) & Change in sugar content & Sutton et al., 2007 \\
\hline Albugo candida & A. thaliana & CWI (+) VI (/) & $\begin{array}{l}\text { Change in sugar content, decrease of starch } \\
\text { content, down-regulation of photosynthesis, } \\
\text { decrease chloropyll content, induction of } \\
\text { defense proteins }\end{array}$ & Chou et al., 2000 \\
\hline $\begin{array}{l}\text { Erysiphe } \\
\text { cichoracearum }\end{array}$ & A. thaliana & CWI (+) & Induction of $H X T$ genes & Fotopoulos et al., 2003 \\
\hline Uromyces fabae & Vicia faba & CWI $(+)$ VI (-) & ND & Voegele et al., 2006 \\
\hline Erysiphe necator & Vitis vinifera & CWI $(+)$ VI (-) & $\begin{array}{l}\text { Induction of } H X T \text { and ABA } \\
\text { biosynthesis-associated genes }\end{array}$ & Hayes et al., 2010 \\
\hline \multicolumn{5}{|l|}{ Hemibiotrophic } \\
\hline Magnaporthe grisea & Rice & CWI (+) & $\begin{array}{l}\text { Change in sugar content, callose deposition, } \\
\text { induction of } P R \text { genes, ROS accumulation }\end{array}$ & $\begin{array}{l}\text { Cho et al., 2005; Sun et al., } \\
2013\end{array}$ \\
\hline \multicolumn{5}{|l|}{ Necrotrophic } \\
\hline Fusarium oxysporum & Tomato & CWI $(+)$ & ND & Benhamou et al., 1991 \\
\hline Botrytis cinerea & Tomato & CWI $(+) \mathrm{VI}(/)$ & ND & Hyun et al., 2011 \\
\hline \multicolumn{5}{|l|}{ Symbiotic } \\
\hline Glomus intraradices & Tomato & CWI $(+)$ & ND & Schaarschmidt et al., 2006 \\
\hline Glomus intraradices & Tobacco & CWI $(+)$ & $\begin{array}{l}\text { Change in sugar content, exchange of nutrients, } \\
\text { decrease chloropyll content, induction of } P R \\
\text { genes }\end{array}$ & Schaarschmidt et al., 2007 \\
\hline \multicolumn{5}{|l|}{ OOMYCETES } \\
\hline $\begin{array}{l}\text { Phytophthora } \\
\text { nicotianae }\end{array}$ & Tobacco & CWI (+) VI (/) A/NInv (+) & $\begin{array}{l}\text { Down-regulation of photosynthesis, callose } \\
\text { deposition, induction of } P R \text { and } P A L \text { genes }\end{array}$ & $\begin{array}{l}\text { Scharte et al., 2005; } \\
\text { Essmann et al., 2008a,b }\end{array}$ \\
\hline Plasmopara viticola & Vitis vinifera & CWI $(+)$ & $\begin{array}{l}\text { Induction of } H X T \text { and } A B A \\
\text { biosynthesis-associated genes }\end{array}$ & Hayes et al., 2010 \\
\hline \multicolumn{5}{|l|}{ RHIZARIA } \\
\hline $\begin{array}{l}\text { Plasmodiophora } \\
\text { brassicae }\end{array}$ & A. thaliana & CWI $(+) \mathrm{VI}(+)$ & ND & Siemens et al., 2011 \\
\hline \multicolumn{5}{|l|}{ NEMATODE } \\
\hline Heterodera schachtii & A. thaliana & CWI (-) VI (-) A/NInv (-) & Change in sugar content & Cabello et al., 2013 \\
\hline Meloidogyne javanica & A. thaliana & $\begin{array}{l}\mathrm{CWI}(-) \mathrm{VI}(-) \mathrm{A} / \mathrm{NInV} \\
(+/-)\end{array}$ & Change in sugar content & \\
\hline \multicolumn{5}{|l|}{ VIRUS } \\
\hline Potato virus $Y$ & Tobacco & CWI (+) VI (/) & $\begin{array}{l}\text { Down-regulation of photosynthesis, induction of } \\
\text { PR genes, callose deposition }\end{array}$ & Herbers et al., 2000 \\
\hline $\begin{array}{l}\text { Beet severe curly top } \\
\text { virus }\end{array}$ & A. thaliana & CWI $(+)$ & $\begin{array}{l}\text { Callus-like structures, induction cell cycle-related } \\
\text { genes }\end{array}$ & Park et al., 2013 \\
\hline
\end{tabular}

Abbreviations: (+), up-regulation; (-), down-regulation; (/), no change; ABA, abscisic acid; HXT, hexose transporter; PR, pathogenesis-related; ROS, reactive oxygen species; SUC, sucrose transporter; ND, not described. 


\section{DEFENSE-INDUCED FEATURES AFFECTED BY SUCROSE AND INVERTASES \\ CLOCK, PHOTOSYNTHESIS, AND SUGAR CONTENT}

The connections between the clock, the sugars and the immunity have been previously presented (Roden and Ingle, 2009; Bolouri Moghaddam and Van Den Ende, 2013) and here we discuss the latest updates on this interconnectivity. Exogenous sucrose is able to stimulate the circadian clock by inhibiting photosynthesis and to coordinate answers during the light-dark cycles (Knight et al., 2008; Dalchau et al., 2011; Haydon et al., 2013). A new metabolic feedback loop involving the morning-expressed pseudo response regulator 7 ( prr7) gene was proposed by Haydon et al. (2013). At dawn, the light activates PRR7 and photosynthesis, then the photosynthetically produced derived sugars accumulate and repress the PRR7 promoter which causes the de-repression of the molecular oscillator component circadian clock associated 1 (CCA1) (Haydon et al., 2013). The clock-related genes (ccal and lhy) affect stomatal aperture after pathogen infection and suggest a crucial role of circadian clock in plant defense response (Wang et al., 2011; Zhang et al., 2013). Diurnal rhythm has been shown to regulate a CWI (LIN6) from tomato and that both CCA1 and LHY activate the Lin6 promoter (Proels and Roitsch, 2009). During pathogen attack, the increase of CWI activity leading to an accumulation of hexoses is associated with a down-regulation of photosynthesis and expression of genes-related to photosynthesis (Table 1). It is noteworthy that transgenic infected plants silenced for CWI showed a delay in the reduction of photosynthesis (Kocal et al., 2008). Thus, the cross-talk between clock, sucrose and invertases tends to illustrate that a fine regulation of the sucrose/hexose ratio is crucial in defense regulation (Haydon et al., 2013).

During the day, both sucrose and starch are produced during photosynthesis. During the night, the starch, accumulated in the chloroplasts, is subsequently degraded to provide substrates for sucrose synthesis. Starch synthesis can be regulated by sucrose and clock by modulating the expression of starch synthase (Wang et al., 2001). After pathogen infection, a decrease in the starch content is observed in the infected region suggesting that the degradation of starch provides more substrates to sucrose synthesis. Interestingly, Engelsdorf et al. tested the susceptibility of starch-free A. thaliana mutants against biotrophic, hemibiotrophic and necrotrophic pathogens and pointed out that depending on the studied pathosystem the diurnal carbon availability is a susceptibility factor (Engelsdorf et al., 2013). Their results imply that sugar availability might impact the ability of plants to trigger defense responses.

One of the other possibilities for changing the sugar content is the regulation of the expression of the sucrose transporter. Sucrose acts on carbohydrate partitioning and phloem loading by modulating the sucrose transporter expression, such as inducing the expression of SUT2 in tomatoes or repressing the expression of BvSUT1 in beet (Barker et al., 2000; Vaughn et al., 2002). Depending on the stage of infection, the expression of sucrose transporters can be altered and as a consequence the sucrose partitioning can be modified. In rice infected by Xanthomonas oryzae pv. Oryzae, SWEET proteins are upregulated and sucrose accumulates in apoplast ready to be used for the pathogen growth
(Chen et al., 2010, 2012). Santi et al. reported a sequential regulation of sucrose transporter genes which are first downregulated during infection of grapevine by stolbur to limit the spread and then upregulated during the recovery stage providing necessary nutrients (Santi et al., 2013a,b). It is noteworthy that during fungal infection the expression of CWI and hexose transporters displayed a correlation enhancing the hexoses supply from the phloem to the surrounding tissues during the transition from source to sink (Fotopoulos et al., 2003; Hayes et al., 2010). Moreover, Hayes et al. reported a relationship between CWI, hexose transporters and $\mathrm{ABA}$ biosynthesis during the transition from source to sink after infection (Hayes et al., 2010).

\section{PHYTOHORMONES}

For different phytohormones such as ABA, gibberellins, ethylene and jasmonate, it was shown that they interact with the sucrose signaling pathway (Finkelstein et al., 2002; Leon and Sheen, 2003; Gibson, 2004; Heil et al., 2012). Their implication in plant defense response and the relationship with sugars have been widely discussed in various reviews (Bolouri Moghaddam and Van Den Ende, 2012, 2013).

\section{PATHOGENESIS RELATED PROTEINS}

PR proteins are synthesized in response to plant pathogen attack. Their classification and their properties have been well described (for reviews see Kitajima and Sato, 1999; Van Loon et al., 2006; Sels et al., 2008). As reported in several studies, the up-regulation of CWI due to the infection goes along with the induction of $P R$ genes (Table 1) such as PR-1a, PR-1b, PR3, PR10, WRKY45, and NPR1 in rice (Sun et al., 2013), PR-1b and PR-Q in tobacco (Herbers et al., 1996; Schaarschmidt et al., 2007; Essmann et al., 2008b) and PR-Q, Pin-II and GluB in tomato (Kocal et al., 2008). During transgenic approaches the overexpression of CWI in tobacco or in rice presented constitutively high levels of $P R$ transcripts compared to the wild type plants (Herbers et al., 1996; Sun et al., 2013). To support this idea, in different cases of infected transgenic plants silenced for CWI, the induction of $P R$ genes was abolished (Schaarschmidt et al., 2007; Essmann et al., 2008b; Kocal et al., 2008). Thus CWI activity is required to enhance the expression of $P R$ genes mediated by the accumulated hexoses which act as signal molecules. Besides, exogenous sucrose induced the expression of $P R$ genes (Thibaud et al., 2004; Gomez-Ariza et al., 2007) confirming the idea of sucrose as an important signal molecule for plant defense response.

\section{PHENYLPROPANOID PATHWAY}

The phenylalanine ammonia-lyase (PAL), a key enzyme which is involved in the phenylpropanoid pathway, leads to the biosynthesis of lignin and the production of many other important compounds such as the flavonoids, coumarins and lignans (for review see Dixon and Paiva, 1995). During infection of lupine by Fusarium oxysporum, sucrose induced the phenylpropanoid metabolism by stimulating the activity of PAL (Morkunas et al., 2005, 2011). Sturm and Chrispeels showed an accumulation of PAL mRNA subsequently to the increase of CWI mRNA in carrot infected by Erwinia carotovora (Sturm and Chrispeels, 1990). Moreover when tobacco plants are silenced for CWI, the PAL 
activity is delayed after infection compared with the wild type plants (Essmann et al., 2008b). Hence, the regulation of PAL is mediated by the variation of the sucrose/hexose ratio. All in all, these results demonstrate that the regulation of the expression of PAL is sugar-related.

Anthocyanin (a flavonoid) has an antimicrobial potential reducing the spread of the pathogens. The synthesis of anthocyanin is regulated by sucrose signaling pathway (Solfanelli et al., 2006) through the induction of the PAP1/MYB75 transcription factor (Teng et al., 2005) and ABA and jasmonate pathways have a synergic effect (Loreti et al., 2008). This induction is repressed by gibberellins. At concentrations of sucrose higher than $2 \%$ the anthocyanin synthesis is induced independently of the ABA signaling pathway (Dai et al., 2014). Recently, a key positive regulator in the sucrose signaling pathway controlling the anthocyanin synthesis has been identified as the DELLA protein which targets PAP1/MYB75 (Li et al., 2014).

In potato tubers, a transcription factor $(A N 1)$ was proposed to up-regulate the phenylpropanoid pathway. The authors suggested that PAL might be induced by AN1 after sucrose feeding. Moreover they proposed a loop in which sucrose increases AN1 expression while AN1 induces sucrolytic enzymes which release hexoses used by the phenylpropanoid pathway (Payyavula et al., 2013). By the synthesis of secondary metabolites such as phenolic compounds or later on lignin, plants produce chemical and physical barriers against pathogens.

\section{CELL WALL REINFORCEMENT}

As another physical barrier, there is the deposition of callose, a $\beta$-(1,3)-glucan cell wall polymer, which is a stress related process limiting invasion by regulating the plasmodesmata and the sieve plates permeability (Chen and Kim, 2009; Luna et al., 2011). In tobacco plants overexpressing a yeast invertase in the apoplast or in the vacuole, the increase of callose deposition was comparable to that observed in wild type plants infected with potato virus $Y$ (Herbers et al., 1996). These results were consistent with a positive regulation of callose deposition by GIF1 in rice after infection by both, bacterial and fungal pathogens (Sun et al., 2013), leading to a regulation mediated by CWI activity. Increasing concentrations of the exogenous sucrose repressed the callose deposition in A. thaliana cells (Luna et al., 2011) suggesting that hexose cleavage products of sucrose are responsible for the formation of the physical barrier against invading pathogens through cell wall reinforcement.

\section{CONCLUSION AND PERSPECTIVES}

Due to a high demand in carbohydrates during infection, plants evolved strategies to modulate their carbohydrate availability and trigger to defense responses. In most of the studied pathosystems, sucrose seems to act as a "priming" agent activating a cascade of signaling pathways such as the modulation of circadian clock genes, phytohormones, cell wall strength and cellular signaling pathways.

A rapid induction of CWIs after infection increases the hexose content and modulates sink strength. It has been demonstrated that CWIs are essential for triggering an appropriate answer during pathogen invasion. The accumulation of hexoses leads to an induction of the $P R$ genes, a down-regulation of the photosynthesis, and an establishment of the chemical and physical barriers. A/NInvs, which are induced afterwards, might be involved in providing more energy during infection. The exact function of the VIs remains unclear but they might release stored carbohydrates and allow reserves mobilization. Moreover, the specificity of plant response depending on the studied pathosystem might be interesting points to investigate.

A better understanding of the "sweet immunity" and the complex network between sucrose, circadian clock and phytohormones might be useful to avoid substantial losses in yield and quality of crops every year. Recently, these biotic elicitors were proposed as interesting elements to generate ready-toeat cruciferous vegetables and maximize their health-promoting compounds (Baenas et al., 2014).

\section{AUTHOR CONTRIBUTIONS}

Alexandra S. Tauzin and Thierry Giardina contribute equally to the writing of this review.

\section{ACKNOWLEDGMENTS}

We would like to gratefully thank Dr. Tyler Yin for assistance in manuscript preparation. This work was supported by the Ministère de l'Enseignement Supérieur et de la Recherche Scientifique.

\section{REFERENCES}

Ausubel, F. M. (2005). Are innate immune signaling pathways in plants and animals conserved? Nat. Immunol. 6, 973-979. doi: 10.1038/ni1253

Baenas, N., Garcia-Viguera, C., and Moreno, D. A. (2014). Biotic elicitors effectively increase the glucosinolates content in brassicaceae sprouts. J. Agric. Food. Chem. 62, 1881-1889. doi: 10.1021/jf404876z

Barker, L., Kuhn, C., Weise, A., Schulz, A., Gebhardt, C., Hirner, B., et al. (2000). SUT2, a putative sucrose sensor in sieve elements. Plant Cell 12, 1153-1164. doi: 10.1105/tpc.12.7.1153

Barratt, D. H., Derbyshire, P., Findlay, K., Pike, M., Wellner, N., Lunn, J., et al. (2009). Normal growth of Arabidopsis requires cytosolic invertase but not sucrose synthase. Proc. Natl. Acad. Sci. U.S.A. 106, 13124-13129. doi: 10.1073/pnas.0900689106

Benhamou, N., Grenier, J., and Chrispeels, M. J. (1991). Accumulation of betafructosidase in the cell walls of tomato roots following infection by a fungal wilt pathogen. Plant Physiol. 97, 739-750. doi: 10.1104/pp.97.2.739

Bolouri Moghaddam, M. R., and Van Den Ende, W. (2012). Sugars and plant innate immunity. J. Exp. Bot. 63, 3989-3998. doi: 10.1093/jxb/ers129

Bolouri Moghaddam, M. R., and Van Den Ende, W. (2013). Sweet immunity in the plant circadian regulatory network. J. Exp. Bot. 64, 1439-1449. doi: 10.1093/jxb/ert046

Bonfig, K. B., Gabler, A., Simon, U. K., Luschin-Ebengreuth, N., Hatz, M., Berger, S., et al. (2010). Post-translational derepression of invertase activity in source leaves via down-regulation of invertase inhibitor expression is part of the plant defense response. Mol. Plant 3, 1037-1048. doi: 10.1093/mp/ssq053

Cabello, S., Lorenz, C., Crespo, S., Cabrera, J., Ludwig, R., Escobar, C., et al. (2013). Altered sucrose synthase and invertase expression affects the local and systemic sugar metabolism of nematode-infected Arabidopsis thaliana plants. J. Exp. Bot. 65, 201-212. doi: 10.1093/jxb/ert359

Chen, L. Q., Hou, B. H., Lalonde, S., Takanaga, H., Hartung, M. L., Qu, X. Q., et al. (2010). Sugar transporters for intercellular exchange and nutrition of pathogens. Nature 468, 527-532. doi: 10.1038/nature09606

Chen, L. Q., Qu, X. Q., Hou, B. H., Sosso, D., Osorio, S., Fernie, A. R., et al. (2012). Sucrose efflux mediated by SWEET proteins as a key step for phloem transport. Science 335, 207-211. doi: 10.1126/science.1213351

Chen, X. Y., and Kim, J. Y. (2009). Callose synthesis in higher plants. Plant Signal. Behav. 4, 489-492. doi: 10.4161/psb.4.6.8359 
Cho, J. I., Lee, S. K., Ko, S., Kim, H. K., Jun, S. H., Lee, Y. H., et al. (2005). Molecular cloning and expression analysis of the cell-wall invertase gene family in rice (Oryza sativa L.). Plant Cell Rep. 24, 225-236. doi: 10.1007/s00299-0040910-z

Cho, J. I., Ryoo, N., Eom, J. S., Lee, D. W., Kim, H. B., Jeong, S. W., et al. (2009). Role of the rice hexokinases OsHXK5 and OsHXK6 as glucose sensors. Plant Physiol. 149, 745-759. doi: 10.1104/pp.108.131227

Cho, Y. H., and Yoo, S. D. (2011). Signaling role of fructose mediated by FINS1/FBP in Arabidopsis thaliana. PLoS Genet. 7:e1001263. doi: 10.1371/journal.pgen.1001263

Chou, H. M., Bundock, N., Rolfe, S. A., and Scholes, J. D. (2000). Infection of Arabidopsis thaliana leaves with Albugo candida (white blister rust) causes a reprogramming of host metabolism. Mol. Plant Pathol. 1, 99-113. doi: 10.1046/j.1364-3703.2000.00013.x

Dai, Z. W., Meddar, M., Renaud, C., Merlin, I., Hilbert, G., Delrot, S., et al. (2014). Long-term in vitro culture of grape berries and its application to assess the effects of sugar supply on anthocyanin accumulation. J. Exp. Bot. doi: 10.1093/jxb/ert489. [Epub ahead of print].

Dalchau, N., Baek, S. J., Briggs, H. M., Robertson, F. C., Dodd, A. N., Gardner, M. J., et al. (2011). The circadian oscillator gene GIGANTEA mediates a long-term response of the Arabidopsis thaliana circadian clock to sucrose. Proc. Natl. Acad. Sci. U.S.A. 108, 5104-5109. doi: 10.1073/pnas.1015452108

Dangl, J. L., and Jones, J. D. (2001). Plant pathogens and integrated defence responses to infection. Nature 411, 826-833. doi: 10.1038/35081161

Dixon, R. A., and Paiva, N. L. (1995). Stress-induced phenylpropanoid metabolism. Plant Cell 7, 1085-1097. doi: 10.1105/tpc.7.7.1085

Engelsdorf, T., Horst, R. J., Prols, R., Proschel, M., Dietz, F., Huckelhoven, R., et al. (2013). Reduced carbohydrate availability enhances the susceptibility of Arabidopsis toward Colletotrichum higginsianum. Plant Physiol. 162, 225-238. doi: 10.1104/pp.112.209676

Essmann, J., Bones, P., Weis, E., and Scharte, J. (2008a). Leaf carbohydrate metabolism during defense: intracellular sucrose-cleaving enzymes do not compensate repression of cell wall invertase. Plant Signal Behav. 3, 885-887. doi: $10.4161 /$ psb.3.10.6501

Essmann, J., Schmitz-Thom, I., Schon, H., Sonnewald, S., Weis, E., and Scharte, J. (2008b). RNA interference-mediated repression of cell wall invertase impairs defense in source leaves of tobacco. Plant Physiol. 147, 1288-1299. doi: 10.1104/pp.108.121418

Finkelstein, R. R., Gampala, S. S., and Rock, C. D. (2002). Abscisic acid signaling in seeds and seedlings. Plant Cell 14(Suppl.), S15-S45. doi: 10.1105/tpc.010441

Fotopoulos, V., Gilbert, M. J., Pittman, J. K., Marvier, A. C., Buchanan, A. J., Sauer, N., et al. (2003). The monosaccharide transporter gene, AtSTP4, and the cellwall invertase, Atbetafruct1, are induced in Arabidopsis during infection with the fungal biotroph Erysiphe cichoracearum. Plant Physiol. 132, 821-829. doi: 10.1104/pp.103.021428

Gibson, S. I. (2004). Sugar and phytohormone response pathways: navigating a signalling network. J. Exp. Bot. 55, 253-264. doi: 10.1093/jxb/erh048

Gomez-Ariza, J., Campo, S., Rufat, M., Estopa, M., Messeguer, J., San Segundo, B., et al. (2007). Sucrose-mediated priming of plant defense responses and broadspectrum disease resistance by overexpression of the maize pathogenesis-related PRms protein in rice plants. Mol. Plant Microbe Interact. 20, 832-842. doi: 10.1094/MPMI-20-7-0832

Greenshields, D. L., Wang, F., Selvaraj, G., and Wei, Y. D. (2004). Activity and gene expression of acid invertases in einkorn wheat (Triticum monococcum) infected with powdery mildew. Can. J. Plant Pathol. Rev. Can. Phytopathol. 26, 506-513. doi: 10.1080/07060660409507171

Greiner, S., Krausgrill, S., and Rausch, T. (1998). Cloning of a tobacco apoplasmic invertase inhibitor. Proof of function of the recombinant protein and expression analysis during plant development. Plant Physiol. 116, 733-742. doi: 10.1104/pp.116.2.733

Haydon, M. J., Mielczarek, O., Robertson, F. C., Hubbard, K. E., and Webb, A. A. (2013). Photosynthetic entrainment of the Arabidopsis thaliana circadian clock Nature 502, 689-692. doi: 10.1038/nature12603

Hayes, M. A., Feechan, A., and Dry, I. B. (2010). Involvement of abscisic acid in the coordinated regulation of a stress-inducible hexose transporter (VvHT5) and a cell wall invertase in grapevine in response to biotrophic fungal infection. Plant Physiol. 153, 211-221. doi: 10.1104/pp.110.154765

Heil, M., Ibarra-Laclette, E., Adame-Alvarez, R. M., Martinez, O., Ramirez-Chavez, E., Molina-Torres, J., et al. (2012). How plants sense wounds: damaged-self recognition is based on plant-derived elicitors and induces octadecanoid signaling. PLoS ONE 7:e30537. doi: 10.1371/journal.pone.0030537

Herbers, K., Meuwly, P., Frommer, W. B., Metraux, J. P., and Sonnewald, U. (1996). Systemic acquired resistance mediated by the ectopic expression of invertase: possible hexose sensing in the secretory pathway. Plant Cell 8, 793-803. doi: 10.1105/tpc.8.5.793

Herbers, K., Takahata, Y., Melzer, M., Mock, H. P., Hajirezaei, M., and Sonnewald, U. (2000). Regulation of carbohydrate partitioning during the interaction of potato virus Y with tobacco. Mol. Plant Pathol. 1, 51-59. doi: 10.1046/j.13643703.2000.00007.x

Hothorn, M., Wolf, S., Aloy, P., Greiner, S., and Scheffzek, K. (2004). Structural insights into the target specificity of plant invertase and pectin methylesterase inhibitory proteins. Plant Cell 16, 3437-3447. doi: 10.1105/tpc.104.025684

Hyun, T. K., Eom, S. H., Rim, Y., and Kim, J. S. (2011). Alteration of the expression and activation of tomato invertases during Botrytis cinerea infection. Plant Omics 4, 413-417.

Jia, L., Zhang, B., Mao, C., Li, J., Wu, Y., Wu, P., et al. (2008). OsCYT-INV1 for alkaline/neutral invertase is involved in root cell development and reproductivity in rice (Oryza sativa L.). Planta 228, 51-59. doi: 10.1007/s00425-008-0718-0

Jones, J. D., and Dangl, J. L. (2006). The plant immune system. Nature 444, 323-329. doi: 10.1038/nature05286

Katagiri, F., and Tsuda, K. (2010). Understanding the plant immune system. Mol. Plant Microbe. Interact. 23, 1531-1536. doi: 10.1094/MPMI-04-10-0099

Kitajima, S., and Sato, F. (1999). Plant pathogenesis-related proteins: molecular mechanisms of gene expression and protein function. J. Biochem. 125, 1-8. doi: 10.1093/oxfordjournals.jbchem.a022244

Knight, H., Thomson, A. J., and McWatters, H. G. (2008). Sensitive to freezing6 integrates cellular and environmental inputs to the plant circadian clock. Plant Physiol. 148, 293-303. doi: 10.1104/pp.108.123901

Kocal, N., Sonnewald, U., and Sonnewald, S. (2008). Cell wall-bound invertase limits sucrose export and is involved in symptom development and inhibition of photosynthesis during compatible interaction between tomato and Xanthomonas campestris pv vesicatoria. Plant Physiol. 148, 1523-1536. doi: $10.1104 /$ pp.108.127977

Koch, K. (2004). Sucrose metabolism: regulatory mechanisms and pivotal roles in sugar sensing and plant development. Curr. Opin. Plant Biol. 7, 235-246. doi: 10.1016/j.pbi.2004.03.014

Lammens, W., Le Roy, K., Schroeven, L., Van Laere, A., Rabijns, A., and Van Den Ende, W. (2009). Structural insights into glycoside hydrolase family 32 and 68 enzymes: functional implications. J. Exp. Bot. 60, 727-740. doi: $10.1093 /$ jxb/ern333

Leon, P., and Sheen, J. (2003). Sugar and hormone connections. Trends Plant Sci. 8, 110-116. doi: 10.1016/S1360-1385(03)00011-6

Li, P., Wind, J. J., Shi, X., Zhang, H., Hanson, J., Smeekens, S. C., et al. (2011). Fructose sensitivity is suppressed in Arabidopsis by the transcription factor ANAC089 lacking the membrane-bound domain. Proc. Natl. Acad. Sci. U.S.A. 108, 3436-3441. doi: 10.1073/pnas.1018665108

Li, Y., Van Den Ende, W., and Rolland, F. (2014). Sucrose induction of anthocyanin biosynthesis is mediated by della. Mol. Plant 7, 570-572. doi: 10.1093/mp/sst161

Loreti, E., Povero, G., Novi, G., Solfanelli, C., Alpi, A., and Perata, P. (2008). Gibberellins, jasmonate and abscisic acid modulate the sucrose-induced expression of anthocyanin biosynthetic genes in Arabidopsis. New Phytol. 179, 1004-1016. doi: 10.1111/j.1469-8137.2008.02511.x

Luna, E., Pastor, V., Robert, J., Flors, V., Mauch-Mani, B., and Ton, J. (2011). Callose deposition: a multifaceted plant defense response. Mol. Plant Microbe Interact. 24, 183-193. doi: 10.1094/MPMI-07-10-0149

Maresca, M. (2013). From the gut to the brain: journey and pathophysiological effects of the food-associated trichothecene mycotoxin deoxynivalenol. Toxins (Basel) 5, 784-820. doi: 10.3390/toxins5040784

Martin, M. L., Lechner, L., Zabaleta, E. J., and Salerno, G. L. (2013). A mitochondrial alkaline/neutral invertase isoform (A/N-InvC) functions in developmental energy-demanding processes in Arabidopsis. Planta 237, 813-822. doi: 10.1007/s00425-012-1794-8

Moore, B., Zhou, L., Rolland, F., Hall, Q., Cheng, W. H., Liu, Y. X., et al. (2003). Role of the Arabidopsis glucose sensor HXK1 in nutrient, light, and hormonal signaling. Science 300, 332-336. doi: 10.1126/science.1080585

Morkunas, I., Marczak, L., Stachowiak, J., and Stobiecki, M. (2005). Sucroseinduced lupine defense against Fusarium oxysporum. Sucrose-stimulated accumulation of isoflavonoids as a defense response of lupine to Fusarium 
oxysporum. Plant Physiol. Biochem. 43, 363-373. doi: 10.1016/j.plaphy.2005. 02.011

Morkunas, I., Narozna, D., Nowak, W., Samardakiewicz, S., and Remlein-Starosta, D. (2011). Cross-talk interactions of sucrose and Fusarium oxysporum in the phenylpropanoid pathway and the accumulation and localization of flavonoids in embryo axes of yellow lupine. J. Plant Physiol. 168, 424-433. doi: 10.1016/j.jplph.2010.08.017

Park, J., Kim, S., Choi, E., Auh, C. K., Park, J. B., Kim, D. G., et al. (2013). Altered invertase activities of symptomatic tissues on Beet severe curly top virus (BSCTV) infected Arabidopsis thaliana. J. Plant Res. 126, 743-752. doi: 10.1007/s10265-013-0562-6

Payyavula, R. S., Singh, R. K., and Navarre, D. A. (2013). Transcription factors, sucrose, and sucrose metabolic genes interact to regulate potato phenylpropanoid metabolism. J. Exp. Bot. 64, 5115-5131. doi: 10.1093/jxb/ert303

Proels, R. K., and Roitsch, T. (2009). Extracellular invertase LIN6 of tomato: a pivotal enzyme for integration of metabolic, hormonal, and stress signals is regulated by a diurnal rhythm. J. Exp. Bot. 60, 1555-1567. doi: 10.1093/jxb/erp027

Roden, L. C., and Ingle, R. A. (2009). Lights, rhythms, infection: the role of light and the circadian clock in determining the outcome of plant-pathogen interactions. Plant Cell 21, 2546-2552. doi: 10.1105/tpc.109.069922

Roitsch, T., and Gonzalez, M. C. (2004). Function and regulation of plant invertases: sweet sensations. Trends Plant Sci. 9, 606-613. doi: 10.1016/j.tplants.2004.10.009

Rolland, F., Baena-Gonzalez, E., and Sheen, J. (2006). Sugar sensing and signaling in plants: conserved and novel mechanisms. Annu. Rev. Plant Biol. 57, 675-709. doi: 10.1146/annurev.arplant.57.032905.105441

Santi, S., De Marco, F., Polizzotto, R., Grisan, S., and Musetti, R. (2013a). Recovery from stolbur disease in grapevine involves changes in sugar transport and metabolism. Front Plant Sci. 4:171. doi: 10.3389/fpls.2013.00171

Santi, S., Grisan, S., Pierasco, A., Marco, F., and Musetti, R. (2013b). Laser microdissection of grapevine leaf phloem infected by stolbur reveals site-specific gene responses associated to sucrose transport and metabolism. Plant Cell Environ. 36, 343-355. doi: 10.1111/j.1365-3040.2012.02577.x

Schaarschmidt, S., Kopka, J., Ludwig-Muller, J., and Hause, B. (2007). Regulation of arbuscular mycorrhization by apoplastic invertases: enhanced invertase activity in the leaf apoplast affects the symbiotic interaction. Plant J. 51, 390-405. doi: 10.1111/j.1365-313X.2007.03150.x

Schaarschmidt, S., Roitsch, T., and Hause, B. (2006). Arbuscular mycorrhiza induces gene expression of the apoplastic invertase LIN6 in tomato (Lycopersicon esculentum) roots. J. Exp. Bot. 57, 4015-4023. doi: 10.1093/jxb/erl172

Scharte, J., Schon, H., and Weis, E. (2005). Photosynthesis and carbohydrate metabolism in tobacco leaves during an incompatible interaction with Phytophthora nicotianae. Plant Cell Environ. 28, 1421-1435. doi: 10.1111/j.1365-3040.2005.01380.x

Scholes, J. D., Lee, P. J., Horton, P., and Lewis, D. H. (1994). Invertase - understanding changes in the photosynthetic and carbohydrate-metabolism of barley leaves infected with powdery mildew. New Phytol. 126, 213-222. doi: 10.1111/j.14698137.1994.tb03939.x

Sels, J., Mathys, J., De Coninck, B. M., Cammue, B. P., and De Bolle, M. F. (2008). Plant pathogenesis-related (PR) proteins: a focus on PR peptides. Plant Physiol. Biochem. 46, 941-950. doi: 10.1016/j.plaphy.2008.06.011

Siemens, J., Gonzalez, M. C., Wolf, S., Hofmann, C., Greiner, S., Du, Y., et al. (2011). Extracellular invertase is involved in the regulation of clubroot disease in Arabidopsis thaliana. Mol. Plant Pathol. 12, 247-262. doi: 10.1111/j.13643703.2010.00667.x

Solfanelli, C., Poggi, A., Loreti, E., Alpi, A., and Perata, P. (2006). Sucrose-specific induction of the anthocyanin biosynthetic pathway in Arabidopsis. Plant Physiol 140, 637-646. doi: 10.1104/pp.105.072579

Sonnewald, S., Priller, J. P., Schuster, J., Glickmann, E., Hajirezaei, M. R., Siebig, S., et al. (2012). Regulation of cell wall-bound invertase in pepper leaves by Xanthomonas campestris pv. vesicatoria type three effectors. PLoS ONE 7:e51763. doi: 10.1371/journal.pone.0051763

Storr, T., and Hall, J. L. (1992). The Effect of Infection by Erysiphe-Pisi Dc on Acid and Alkaline Invertase Activities and Aspects of Starch Biochemistry in Leaves of Pisum-Sativum L. New Phytol. 121, 535-543. doi: 10.1111/j.14698137.1992.tb01123.x

Sturm, A., and Chrispeels, M. J. (1990). cDNA cloning of carrot extracellular beta-fructosidase and its expression in response to wounding and bacterial infection. Plant Cell 2, 1107-1119.
Sun, L., Yang, D. L., Kong, Y., Chen, Y., Li, X. Z., Zeng, L. J., et al. (2013). Sugar homeostasis mediated by cell wall invertase GRAIN INCOMPLETE FILLING 1 (GIF1) plays a role in pre-existing and induced defence in rice. Mol. Plant. Pathol. 15, 161-173. doi: 10.1111/mpp.12078

Sutton, P. N., Gilbert, M. J., Williams, L. E., and Hall, J. L. (2007). Powdery mildew infection of wheat leaves changes host solute transport and invertase activity. Physiol. Plant. 129, 787-795. doi: 10.1111/j.1399-3054.2007.00863.x

Swarbrick, P. J., Schulze-Lefert, P., and Scholes, J. D. (2006). Metabolic consequences of susceptibility and resistance (race-specific and broad-spectrum) in barley leaves challenged with powdery mildew. Plant Cell Environ. 29, 1061-1076. doi: 10.1111/j.1365-3040.2005.01472.x

Tauzin, A. S., Sulzenbacher, G., Lafond, M., Desseaux, V., Reca, I. B., Perrier, J., et al. (2014). Functional characterization of a vacuolar invertase from Solanum lycopersicum: post-translational regulation by $\mathrm{N}$-glycosylation and a proteinaceous inhibitor. Biochimie 101, 39-49. doi: 10.1016/j.biochi.2013.12.013

Teng, S., Keurentjes, J., Bentsink, L., Koornneef, M., and Smeekens, S. (2005). Sucrose-specific induction of anthocyanin biosynthesis in Arabidopsis requires the MYB75/PAP1 gene. Plant Physiol. 139, 1840-1852. doi: 10.1104/pp.105.066688

Tetlow, I. J., and Farrar, J. F. (1992). Sucrose-Metabolizing Enzymes from leaves of barley infected with brown rust (Puccinia-Hordei Otth). New Phytol. 120, 475-480. doi: 10.1111/j.1469-8137.1992.tb01795.x

Thibaud, M. C., Gineste, S., Nussaume, L., and Robaglia, C. (2004). Sucrose increases pathogenesis-related PR-2 gene expression in Arabidopsis thaliana through an SA-dependent but NPRl-independent signaling pathway. Plant Physiol. Biochem. 42, 81-88. doi: 10.1016/j.plaphy. 2003.10.012

Thines, E., Weber, R. W., and Talbot, N. J. (2000). MAP kinase and protein kinase A-dependent mobilization of triacylglycerol and glycogen during appressorium turgor generation by Magnaporthe grisea. Plant Cell 12, 1703-1718. doi: 10.1105/tpc.12.9.1703

Tognetti, J. A., Pontis, H. G., and Martinez-Noel, G. M. (2013). Sucrose signaling in plants: A world yet to be explored. Plant Signal Behav. 8:e23316. doi: $10.4161 /$ psb. 23316

Van Loon, L. C., Rep, M., and Pieterse, C. M. (2006). Significance of inducible defense-related proteins in infected plants. Annu. Rev. Phytopathol. 44, 135-162. doi: 10.1146/annurev.phyto.44.070505.143425

Vargas, W. A., and Salerno, G. L. (2010). The Cinderella story of sucrose hydrolysis: Alkaline/neutral invertases, from cyanobacteria to unforeseen roles in plant cytosol and organelles. Plant Sci. 178, 1-8. doi: 10.1016/j.plantsci.2009. 09.015

Vaughn, M. W., Harrington, G. N., and Bush, D. R. (2002). Sucrose-mediated transcriptional regulation of sucrose symporter activity in the phloem. Proc. Natl. Acad. Sci. U.S.A. 99, 10876-10880. doi: 10.1073/pnas.172198599

Voegele, R. T., Wirsel, S., Moll, U., Lechner, M., and Mendgen, K. (2006). Cloning and characterization of a novel invertase from the obligate biotroph Uromyces fabae and analysis of expression patterns of host and pathogen invertases in the course of infection. Mol. Plant Microbe Interact. 19, 625-634. doi: 10.1094/MPMI-19-0625

Wachter, R., Langhans, M., Aloni, R., Gotz, S., Weilmunster, A., Koops, A., et al. (2003). Vascularization, high-volume solution flow, and localized roles for enzymes of sucrose metabolism during tumorigenesis by Agrobacterium tumefaciens. Plant Physiol. 133, 1024-1037. doi: 10.1104/pp.103. 028142

Wang, S. J., Yeh, K. W., and Tsai, C. Y. (2001). Regulation of starch granulebound starch synthase I gene expression by circadian clock and sucrose in the source tissue of sweet potato. Plant Sci. 161, 635-644. doi: 10.1016/S01689452(01)00449-6

Wang, W., Barnaby, J. Y., Tada, Y., Li, H., Tor, M., Caldelari, D., et al. (2011) Timing of plant immune responses by a central circadian regulator. Nature 470, 110-114. doi: 10.1038/nature09766

Welham, T., Pike, J., Horst, I., Flemetakis, E., Katinakis, P., Kaneko, T., et al. (2009). A cytosolic invertase is required for normal growth and cell development in the model legume, lotus japonicus. J. Exp. Bot. 60, 3353-3365. doi: 10.1093/jxb/erp169

Wind, J., Smeekens, S., and Hanson, J. (2010). Sucrose: metabolite and signaling molecule. Phytochemistry 71, 1610-1614. doi: 10.1016/j.phytochem.2010. 07.007

Wright, D. P., Baldwin, B. C., Shephard, M. C., and Scholes, J. D. (1995). Sourcesink relationships in wheat leaves infected with powdery mildew.1. Alterations 
in carbohydrate-metabolism. Physiol. Mol. Plant Pathol. 47, 237-253. doi: 10.1006/pmpp.1995.1055

Xiang, L., Le Roy, K., Bolouri-Moghaddam, M. R., Vanhaecke, M., Lammens, W., Rolland, F., et al. (2011). Exploring the neutral invertase-oxidative stress defence connection in Arabidopsis thaliana. J. Exp. Bot. 62, 3849-3862. doi: 10.1093/jxb/err069

Zhang, C., Xie, Q., Anderson, R. G., Ng, G., Seitz, N. C., Peterson, T., et al. (2013). Crosstalk between the circadian clock and innate immunity in Arabidopsis. PLoS Pathog. 9:e1003370. doi: 10.1371/journal.ppat.1003370

Conflict of Interest Statement: The authors declare that the research was conducted in the absence of any commercial or financial relationships that could be construed as a potential conflict of interest.
Received: 14 February 2014; accepted: 04 June 2014; published online: 23 June 2014. Citation: Tauzin AS and Giardina T (2014) Sucrose and invertases, a part of the plant defense response to the biotic stresses. Front. Plant Sci. 5:293. doi: 10.3389/fpls. 2014.00293

This article was submitted to Plant-Microbe Interaction, a section of the journal Frontiers in Plant Science.

Copyright (c) 2014 Tauzin and Giardina. This is an open-access article distributed under the terms of the Creative Commons Attribution License (CC BY). The use, distribution or reproduction in other forums is permitted, provided the original author(s) or licensor are credited and that the original publication in this journal is cited, in accordance with accepted academic practice. No use, distribution or reproduction is permitted which does not comply with these terms. 